\title{
PARADIGMA KEMISKINAN \\ DALAM PERSPEKTIF ISLAM DAN KONVENSIONAL
}

\author{
Husna Ni'matul Ulya \\ Institut Agama Islam Negeri Ponorogo \\ email: husnaulya8586@gmail.com
}

\begin{abstract}
Poverty is a condition where a person or groups of people, male and female, are unable to fulfill their basic rights to maintain and develop a dignified life. The dimensions of poverty are interrelated, both directly and indirectly, it means that progress and setbacks in one aspect can affect progress and decline in other aspects, and another aspect of poverty is that the poor are human beings, either individual or collective. The latest data in March 2018 mentions that the number of poverty in Indonesia as many as 25, 95 millions of people. The causes of poverty vary, depending on the type of poverty itself, as well as there are many different poverty indicators. Poverty reduction efforts are carried out by providing basic needs such as food, health and education services, expansion of employment opportunities, agricultural development, and provision of revolving funds through the credit system, infrastructure development and assistance, sanitation counseling and so on. Islam provides solutions to solve the poverty alleviation such as working obligation, income redistribution (zakat), infaq, etc.
\end{abstract}

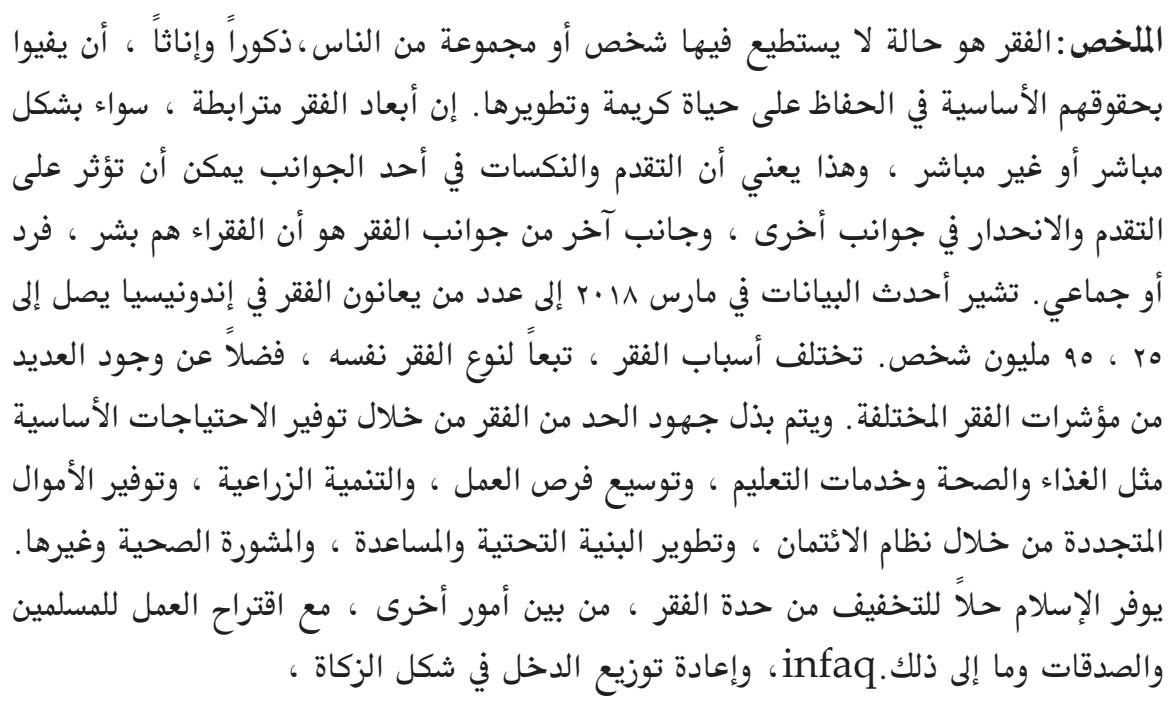


Abstrak: Kemiskinan sebagai kondisi dimana seseorang atau sekelompok orang, laki-laki dan perempuan, tidak mampu memenuhi hak-hak dasarnya untuk mempertahankan dan mengembangkan kehidupan yang bermartabat. Dimensi-dimensi kemiskinan saling berkaitan, baik secara langsung maupun tak langsung, hal ini berarti bahwa kemajuan dan kemunduran pada salah satu aspek dapat mempengaruhi kemajuan dan kemunduran pada aspek lainnya, dan aspek lainnya dari kemiskinan ini adalah bahwa yang miskin itu adalah manusianya, baik secara individual maupun kolektif. Data terakhir pada bulan Maret tahun 2018 menyebutkan jumlah kemiskinan di Indonesia sebanyak 25, 95 juta penduduk. Penyebab kemiskinan berbeda-beda, tergantung dengan jenis kemiskinan itu sendiri, begitu pula ada banyak indikator kemiskinan yang berbeda-beda. upaya penanggulangan kemiskinan dilakukan dengan penyediaan kebutuhan dasar seperti pangan, pelayanan kesehatan dan pendidikan, perluasan kesempatan kerja, pembangunan pertanian, pemberian dana bergulir melalui sistem kredit, pembangunan prasarana dan pendampingan, penyuluhan sanitasi dan sebagainya. Islam memberikan solusi dalam pengentasan kemiskinan, antara lain dengan adanya anjuran untuk bekerja bagi umat muslim, adanya redistribusi pendapatan berupa zakat, infaq dan sedekah dan lain sebagainya.

Keyword: kemiskinan, Islam, pengentasan kemiskinan.

\section{PENDAHULUAN}

Proses pembangunan membutuhkan aspek pendukung demi kelancaran menuju hasil pembangunan yang ingin dicapai oleh suatu negara, di negara-negara yang sedang berkembang banyak faktor yang harus dicapai untuk mengalami transformasi menjadi negara maju, di awal tahun 1970-an terjadi perubahan luar biasa berkenaan dengan persepsi pemerintah dan masyarakat mengenai tujuan utama kegiatan ekonomi. Di negara sedang berkembang yang menjadi perhatian utama adalah masalah pertumbuhan versus distribusi pendapatan, banyak NSB (Negara Sedang Berkembang) yang mengalami tingkat pertumbuhan ekonomi yang tinggi pada tahun 
1960-an mulai menyadari bahwa pertumbuhan semacam itu hanya sedikit manfaatnya dalam memecahkan masalah kemiskinan. Bagi ratusan juta rakyat Afrika, Asia dan Amerika latin tingkat kehidupan tampaknya mengalami penurunan, tingkat pengangguran meningkat pada daerah pedesaan dan perkotaan, distribusi pendapatan antara orang kaya dan orang miskin semakin tidak merata, banyak orang merasakan bahwa pertumbuhan ekonomi yang tinggi telah gagal untuk menghilangkan atau bahkan mengurangi luasnya kemiskinan absolut di NSB.

Dari data BPS jumlah penduduk miskin di Indonesia masih banyak, sensus terakhir pada Maret 2011, data menunjukkan bahwa jumlah penduduk miskin (penduduk dengan pengeluaran per kapita per bulan di bawah garis kemiskinan) di Indonesia pada Maret 2011 mencapai 30,02 juta orang (12,49\%), mengalami penurunan dari 31,02 pada Maret 2010, dengan jumlah penduduk miskin di perkotaan 11,05 juta orang dan di pedesaan berjumlah 18,97 juta orang, dari tahun 2010 hingga tahun 2011 jumlah penduduk miskin mengalami penurunan, hingga tahun 2017 sebanyak 26,58 juta orang dan data terakhir sebanyak 25,95 juta penduduk miskin pada Maret tahun 2018. ${ }^{1}$ Namun demikian, secara absolut jumlah penduduk yang masih hidup di bawah garis kemiskinan ternyata masih banyak, selain itu masih banyak penduduk yang pendapatannya sedikit sekali diatas batas garis kemiskinan. Kelompok "nyaris miskin" ini sangat rawan terhadap perubahan-perubahan keadaan ekonomi seperti kenaikan harga komoditi-komoditi utama atau turunnya tingkat pertumbuhan ekonomi, oleh karena itu masalah kemiskinan ini masih tetap perlu diperhatikan secara serius karena tujuan pembangunan Indonesia adalah pembangunan manusia seutuhnya.

Menurut para ahli ${ }^{2}$, kemiskinan itu bersifat multidimensi, artinya karena kebutuhan manusia itu bermacam-macam, maka kemiskinan pun memiliki banyak aspek. Dilihat dari kebijakan umum, maka

\footnotetext{
${ }^{1}$ Kompas, 16 Juli 2018.

${ }^{2}$ Antara lain Andre Bayo Ala, 1981.
} 
kemiskinan memiliki aspek primer yang berupa miskin atas aset, organisasi sosial politik, dan pengetahuan, serta keterampilan. Aspek sekunder berupa miskin akan jaringan sosial, sumber-sumber keuangan dan informasi. Kemiskinan tersebut termanifestasikan dalam bentuk kekurangan gizi, air, perumahan yang sehat, perawatan kesehatan yang kurang baik, dan tingkat pendidikan yang rendah. Selain itu, dimensi-dimensi kemiskinan saling berkaitan, baik secara langsung maupun tak langsung, hal ini berarti bahwa kemajuan dan kemunduran pada salah satu aspek dapat mempengaruhi kemajuan dan kemunduran pada aspek lainnya, dan aspek lainnya dari kemiskinan ini adalah bahwa yang miskin itu adalah manusianya, baik secara individual maupun kolektif.

Kemiskinan terus menjadi masalah fenomenal sepanjang sejarah Indonesia sebagai nation state, sejarah sebuah negara yang salah memandang dan mengurus kemiskinan. Kemiskinan telah membuat jutaan anak-anak tidak bisa mengenyam pendidikan yang berkualitas, kesulitan membiayai kesehatan, kurangnya tabungan dan tidak adanya investasi, kurangnya akses ke pelayanan publik, kurangnya lapangan pekerjaan, kurangnya jaminan sosial dan perlindungan terhadap keluarga, menguatnya arus urbanisasi ke kota, dan yang lebih parah, kemiskinan menyebabkan jutaan rakyat memenuhi kebutuhan pangan, sandang dan papan secara terbatas. Kemiskinan, menyebabkan masyarakat desa rela mengorbankan apa saja demi keselamatan hidup, safety life 3 , mempertaruhkan tenaga fisik untuk memproduksi keuntungan bagi tengkulak lokal dan menerima upah yang tidak sepadan dengan biaya tenaga yang dikeluarkan. Para buruh tani desa bekerja sepanjang hari, tetapi mereka menerima upah yang sangat sedikit.

Kemiskinan telah membatasi hak rakyat untuk: 1) memperoleh pekerjaan yang layak bagi kemanusiaan; 2) Hak rakyat untuk memperoleh perlindungan hukum; 3) Hak rakyat untuk memperoleh rasa aman; 4) Hak rakyat untuk memperoleh akses atas kebutuhan hidup

${ }^{3}$ James. C. Scott, 1981. 
(sandang, pangan, dan papan) yang terjangkau; 5) Hak rakyat untuk memperoleh akses atas kebutuhan pendidikan; 6) Hak rakyat untuk memperoleh akses atas kebutuhan kesehatan; 7) Hak rakyat untuk memperoleh keadilan; 8) Hak rakyat untuk berpartisipasi dalam pengambilan keputusan publik dan pemerintahan; 9) Hak rakyat untuk berinovasi; 10) Hak rakyat menjalankan hubungan spiritualnya dengan Tuhan; dan 11) Hak rakyat untuk berpartisipasi dalam menata dan mengelola pemerintahan dengan baik. ${ }^{4}$

Selama tiga dekade, upaya penanggulangan kemiskinan dilakukan dengan penyediaan kebutuhan dasar seperti pangan, pelayanan kesehatan dan pendidikan, perluasan kesempatan kerja, pembangunan pertanian, pemberian dana bergulir melalui sistem kredit, pembangunan prasarana dan pendampingan, penyuluhan sanitasi dan sebagainya. Dari serangkaian cara dan strategi penanggulangan kemiskinan tersebut, semuanya berorentasi material, sehingga keberlanjutannya sangat tergantung pada ketersediaan anggaran dan komitmen pemerintah. Di samping itu, tidak adanya tatanan pemerintahan yang demokratis menyebabkan rendahnya akseptabilitas dan inisiatif masyarakat untuk menanggulangi kemiskinan dengan cara mereka sendiri.

Agama Islam merupakan agama rohmatan li al-alamin, sehingga memandang masalah kemiskinan ini adalah masalah yang wajib diperhatikan, bahkan Ali bin Abi T\{alib berkata "Seandainya kemiskinan berwujud manusia, niscaya aku akan membunuhnya", sedemikian penting masalah kemiskinan ini, karena jika kemiskinan merajalela, akan banyak kerusakan dan kehancuran di muka bumi ini, akan banyak kejahatan akibat penderitaan dari kekurangan, penanggulangan kemiskinan dilakukan dalam rangka menyelamatkan aqidah, akhlak dan laku perbuatan, memelihara kehidupan rumah tangga, dan melindungi kestabilan dan ketenteraman masyarakat, di samping mewujudkan jiwa persaudaraan antara sesama anggota masyarakat. Islam

${ }^{4}$ Gregorius Sahdan, “Menanggulangi Kemiskinan”, Jurnal Ekonomi Rakyat. Edisi Maret 2005. 
memberikan solusi agar manusia giat bekerja dan berusaha ungtuk kehidupannya agar tidak terjerumus ke lembah kemiskinan, serta menganjurkan umatnya untuk peduli kepada sesama serta senang memberikan bantuan kepada saudara-saudara yang membutuhkan.

Dalam artikel ini akan mencoba memaparkan tentang apa itu kemiskinan, faktor dan aspek apa sajakah yang melingkupi adanya kemiskinan, serta langkah-langkah apa sajakah yang bisa dilakukan dalam tujuan pengentasan kemiskinan.

\section{MAKNA DAN DEFINISI KEMISKINAN}

Kemiskinan memiliki dimensi yang luas, BAPPENAS (2004) mendefinisikan kemiskinan sebagai kondisi dimana seseorang atau sekelompok orang, laki-laki dan perempuan, tidak mampu memenuhi hak-hak dasarnya untuk mempertahankan dan mengembangkan kehidupan yang bermartabat. Hak-hak dasar masyarakat desa antara lain, terpenuhinya kebutuhan pangan, kesehatan, pendidikan, pekerjaan, perumahan, air bersih, pertanahan, sumberdaya alam dan lingkungan hidup, rasa aman dari perlakukan atau ancaman tindak kekerasan dan hak untuk berpartisipasi dalam kehidupan sosialpolitik, baik bagi perempuan maupun laki-laki.

Dalam Wikipedia disebutkan Fundamentally, poverty is a denial of choices and opportunities, a violation of human dignity. It means lack of basic capacity to participate effectively in society. It means not having enough to feed and clothe a family, not having a school or clinic to go to, not having the land on which to grow one's food or a job to earn one's living, not having access to credit. It means insecurity, powerlessness and exclusion of individuals, households and communities. It means susceptibility to violence, and it often implies living in marginal or fragile environments, without access to clean water or sanitation. In another definition, poverty is pronounced deprivation in well-being, and comprises many dimensions. It includes low incomes and the inability to acquire the basic goods and services necessary for survival with dignity. Poverty also encompasses low levels of health and education, poor access to clean water and sanitation, inadequate physical security, lack of voice, and insufficient capacity and opportunity to better one's life. 
Menurut Islam, fakir miskin adalah orang/keluarga yang sama sekali tidak mempunyai sumber mata pencaharian dan tidak mempunyai kemampuan untuk memenuhi kebutuhan hidup yang layak bagi kemanusiaan atau orang/keluarga yang mempunyai sumber mata pencaharian, tapi tidak dapat memenuhi kebutuhan yang layak bagi kemanusiaan. ${ }^{5}$ Menurut bahasa, miskin berasal dari bahasa Arab yang sebenarnya menyatakan kefakiran yang sangat. Allah Swt menggunakan istilah itu dalam firman-Nya:

"......atau kepada orang miskin yang sangat fakir"6 (QS Al-Balad 90:16)

Adapun kata fakir yang berasal dari bahasa Arab al-faqru, berarti membutuhkan (al-ihtiyāj). Seperti firman Allah Swt :

"Maka Musa memberi minum ternak itu untuk (menolong) keduanya, kemudian Dia kembali ke tempat yang teduh lalu berdoa: Ya Tuhanku Sesungguhnya aku sangat memerlukan sesuatu kebaikan ${ }^{7}$ yang Engkau turunkan kepadaku"8.( QS Al-Qashash 28:24)

Al-Qur'an memiliki definisi dalam mengartikan kemiskinan, diantaranya adalah:

al-Maskanāt (المسكنات), Menurut al-Raghỉb al-Ashfahaniy, kata almaskanat dari segi bentuknya, termasuk al-s\}ifat al-mushabbahat (kata yang menunjukkan keadaan dan tidak terikat dengan waktu) dan menunjukkan pada orang yang tidak mempunyai harta benda. Kata ini dibentuk dari fi'il madhi (kata kerja bentuk lampau) sakana yang berarti diamnya sesuatu sedudah bergerak, dan bertempat tinggal. Bentuk masdarnya adalah maskanat (kemiskinan). Al-Qur'an banyak menyoroti kemiskinan sebagai persoalan manusia atau sifat yang berhubungan dengan diri manusia. Pengertian kata miskin dari segi

${ }^{5}$ PP No. 42/1981.

${ }^{6}$ al-Qur'an, 90:16.

${ }^{7}$ Yang dimaksud dengan Khair (kebaikan) dalam ayat ini menurut sebagian besar ahli tafsir ialah barang sedikit makanan.

${ }^{8}$ Ibid. 
leksikal sebagaimana dikemukakan diatas mengacu pada dimensi ekonomi atau kemiskinan materi.

al-Faqr (الفر) ,Menurut Dar al-Masyriq (Hamdar Arraiyyah, 2007: 19), al-Faqr termasuk jenis ism (kata benda) bentuk masdar. Artinya kemiskinan. Kata kerja bentuk lampaunya adalah faqura. Al-Faqr (jamaknya faqara) termasuk jenis kata sifat (al-s\}ifat al-mushabbahat), berarti miskin. Jenis kata yang disebut terakhir menunjuk kepada melekatnya sifat pada pemiliknya secara mutlak, tidak terikat oleh waktu seperti keterikatan isim fá'il (kata benda yang menunjukkan pelaku). Sebutan lengkapnya al-s\}ifat al-mushabbahat bi ism al fa'il (kata sifat yang dianggap serupa dengan kata benda yang menunjuk pelaku).

Dari segi etimologi, al-faqir berarti orang yang patah tulang belakangnya. Kata ini kemudian dipergunakn untuk orang miskin. Ia seolah-olah patah tulang belakangnya karena kemiskinan dan kesengsaraan (Ibn Zakariya dalam Hamdar Arraiyyah, 2007: 20) Dengan demikian, kemiskinan yang ditunukkan oleh kata al-fagr mengarah kepada segi material.

al-'Ailat (العاءلة), Menurut al-Raghỉb al-Ashfahaniy (Hamdar Arraiyyah, 2007: 26), al-'Ailat adalah kata benda bentuk masdar yang berarti kemiskinan. Kata kerja bentuk lampaunya adalah 'ala (mengalami kemiskinan). Kata benda yang menunjukkan kepada penyandang kemiskinan (ism al-fá'il) disebut fá'il.

al-Ba'sa (البأس), Kata Al-Ba'sa terambil dari kata al-bu's (bentuk masdar) dan berarti kesulitan karena kemiskinan. al-Bu's, menurut Al-Zakariya (Hamdar Arraiyyah, 2007: 28) berarti kesulitan dalam penghidupan. Kata kerja lampaunya adalah $b a^{\prime} u s a$. al-Ba'sa dikemukakan dalam 4 gagasan pokok, yaitu: (1) bersabar dalam kesempitan dan penderitaan merupakan salah satu unsur dari al-birr (kebajikan), (2) malapetaka dan kesengsaraan merupakan cobaan bagi calon penghuni surga sebagaimana hal itu telah ditimpakan kepada umat-umat terdahulu, (3) kesengsaraan dan kemelaratan yang ditimpakan kepada umat terdahulu dimaksudkan agar mereka itu memohon kepada Allah dengan merendahkan diri, (4) kesempitan dan penderitaan merupakan ujian yang selalu menyertai kedatangan seorang rasul 
Allah kepada penduduk negeri yang mendustakan kedatangannya agar mereka itu tunduk dan mendekatkan diri kepada Allah.

al-Imlaq (الإملاق), Imlāq adalah kata benda bentuk masdar. Kata kerja bentuk lampaunya amlaqa. Artinya menghabiskan harta benda sehingga menjadi orang yang kekurangan (A-Zakariya dalam Hamdar Arraiyyah, 2007: 31). Dengan demikian, dari segi leksikal, kemiskinan yang ditunjuk oleh kata itu terikat dengan tindakan manusia berkenaan dengan harta benda.

al-Sāil (السائل, Menurut Yūsuf al-Qard\}awiy (Hamdar Arraiyyah, 2007: 34) al-Säil adalah ism al-fá'il (kata benda yang menunjuk kepada pelaku perbuatan). Ia terbentuk dari kerja saala yang artinya meminta kebaikan atau sesuatu yang dapat membawa kepada kebaikan, meminta harta atau sesuatu yang dapat menghasilkan harta. Jadi dari segi leksikal, al-sāil adalah orang yang meminta sesuatu, baik itu immaterial seperti informasi atau berupa materi seperti upah atau uang.

al-Mah\{rūm (المحروم)Bentuk jamak dari al-mah\{rūm yakni muhrumun. Dalam AlQur'an, kata ini dipergunakan dalam arti orang yang dilarang untuk memperoleh hasil kebunnya, atau tidak mendapatkan hasil sama sekali. Jadi, pemakaian kata ini dalam bentuk jamak tidak menunjukkan kepada arti miskin, namun menunjuk pada keadaan yang serupa dengan apa yang dialami oleh orang miskin yang tidak mendapatkan apa-apa.

al-Qāni' (القانع), Menurut al-Raghỉb al-Ashfahaniy, al-Qāni' adalah kata benda yang menunjuk kepada pelaku. Ia bisa dibentuk dari kata bentuk lampau qani'a yang berarti merasa senang dan bisa dari qana'a yang berarti meminta. Menurut sebagian ahli bahasa, al-qāni' adalah meminta yang tidak nyinyir dan merasa senang dengan apa yang diperoleh. Yūsuf 'Ali mengemukakan bahwa dalam mengemis itu ada etika, seperti halnya berderma. Meminta dengan cara yang congkak dan kurang sopan tidak dibenarkan, meskipun segala macam kesukaran itu, baik yang wajar maupun yang tidak semestinya perlu diberi uluran tangan.

al-Mu'tar (المعتر), Menurut Mahmud Hijazay , al-Mu'tarr berarti orang miskin yang datang meminta. Ia sama dengan al-qāni' selaku 
penyandang kemiskinan, namun berbeda dari segi penampilan lahiriahnya. Untuk mendapatkan apa yang dicari, ia mendatangi seseorang dengan cara meminta atau diam. Pemakaian kata al-mu'tarr dengan pengertian seperti disebutkan di atas ternyata lebih luas dari pengertian leksikalnya, yaitu orang yang datang untuk mendapatkan sesuatu yang lazim dikenal dari orang lain tanpa meminta.

al-D\{a'if dan al-Mustad\{'at (الضعيف)/(المسثعات), Menurut al-Raghib al-Ashfahaniy, al-D\}a'if adalah al-s\}ifat al-mushabbahat yang berarti lemah atau orang lemah. Ia dibentuk dari kata kerja lampau d\} a'ufa yang artinya menjadi lemah. Bentuk masdarnya al-d\}a'f berarti kelemahan atau antonim dari kekuatan. Kelemahan bisa terjadi pada jiwa, fisik, dan keadaan.

Dalam pengertian yang lebih definitif, Syekh An-Nabhani mengkategorikan yang punya harta (uang), tetapi tak mencukupi kebutuhan pembelanjaannya sebagai orang fakir. Sementara itu, orang miskin adalah orang yang tak punya harta (uang), sekaligus tak punya penghasilan'. Pembedaan kategori ini tepat untuk menjelaskan pengertian dua pos mustahiq zakat, yakni al-fuqarā' (orang-orang faqir) dan al-masākỉn (orang-orang miskin), sebagaimana firman-Nya: QS atTaubah 60

"Sesungguhnya zakat-zakat itu, hanyalah untuk orang-orang fakir, orang-orang miskin, pengurus-pengurus zakat, Para mu'allaf yang dibujuk hatinya, untuk (memerdekakan) budak, orang-orang yang berhutang, untuk jalan Allah dan untuk mereka yuang sedang dalam perjalanan, sebagai suatu ketetapan yang diwajibkan Allah, dan Allah Maha mengetahui lagi Maha Bijaksana ${ }^{10 \prime}$. (QS At-Taubah 9:60)

9 Taqiyuddin an- Nabhani, Nidzamul Iqtishadi fil Islam, (Beirut: Darul Ummah,1990), 236.

${ }^{10}$ Yang berhak menerima zakat Ialah: 1. orang fakir: orang yang Amat sengsara hidupnya, tidak mempunyai harta dan tenaga untuk memenuhi penghidupannya. 2. orang miskin: orang yang tidak cukup penghidupannya dan dalam Keadaan kekurangan. 3. Pengurus zakat: orang yang diberi tugas untuk mengumpulkan dan membagikan zakat. 4. Muallaf: orang kafir yang ada harapan masuk Islam dan orang yang baru masuk Islam yang imannya masih lemah. 5. memerdekakan budak: mencakup juga untuk melepaskan Muslim yang ditawan oleh orang-orang kafir. 6. orang berhutang: orang yang berhutang karena untuk kepentingan yang bukan 
Kemiskinan adalah keadaan dimana terjadi ketidakmampuan untuk memenuhi kebutuhan dasar seperti makanan, pakaian, tempat berlindung, pendidikan, dan kesehatan. Kemiskinan dapat disebabkan oleh kelangkaan alat pemenuh kebutuhan dasar, ataupun sulitnya akses terhadap pendidikan dan pekerjaan. Islam memandang kemiskinan ini adalah tidak terpenuhinya kebutuhan primer (sandang, pangan, papan) jika hal ini tidak dapat terpenuhi, maka akan berimplikasi pada kemunduran eksistensi manusia.

Kemiskinan merupakan ketakberdayaan sekelompok masyarakat terhadap sistem yang diterapkan oleh suatu pemerintahan sehingga mereka berada pada posisi yang sangat lemah dan tereksploitasi (kemiskinan struktural). Tetapi pada umumnya, ketika orang berbicara tentang kemiskinan, yang dimaksud adalah kemiskinan material. Dengan pengertian ini, maka seseorang masuk dalam kategori miskin apabila tidak mampu memenuhi standar minimum kebutuhan pokok untuk dapat hidup secara layak, yang disebut dengan kemiskinan konsumsi sehingga definisi ini masih kurang memadai di dalam perumusan solusi pengentasan kemiskinan.

\section{FAKTOR-FAKTOR PENYEBAB KEMISKINAN}

Kemiskinan merupakan siklus panjang yang masih membutuhkan pemecahan yang kompleks dan mendetail, sehingga dalam hal ini perlu adanya identifikasi akar/faktor penyebab kemiskinan itu sendiri, sehingga akan teridentifikasi solusi untuk mengentaskan kemiskinan, diantara faktor-faktor penyebab kemiskinan itu sendiri terjabarkan dari berbagai sumber, salah satu sumber referensi ${ }^{11}$ menyebutkan faktor-faktor penyebab kemiskinan adalah:

maksiat dan tidak sanggup membayarnya. Adapun orang yang berhutang untuk memelihara persatuan umat Islam dibayar hutangnya itu dengan zakat, walaupun ia mampu membayarnya. 7. pada jalan Allah (sabilillah): Yaitu untuk keperluan pertahanan Islam dan kaum muslimin. di antara mufasirin ada yang berpendapat bahwa fisabilillah itu mencakup juga kepentingan-kepentingan umum seperti mendirikan sekolah, rumah sakit dan lain-lain. 8. orang yang sedang dalam perjalanan yang bukan maksiat mengalami kesengsaraan dalam perjalanannya.

${ }^{11}$ Antonio Pradjasto Harjono, dkk. Mendahulukan Si Miskin-Buku Sumber bagi Anggaran pro rakyat, (Yogyakarta: LKIS, 2008), 23. 
Pertama, hal yang jelas adalah minimnya atau bahkan tidak adanya kesempatan kerja, jika suatu keluarga tidak mendapatkan pekerjaan, apapun alasannya di negara tanpa kebijakan asuransi, maka secara otomatis akan menjadi keluarga miskin.

Kedua, kemiskinan disebabkan karena hilangnya habitat dan kerusakan lingkungan, misalnya jika seorang petani harus menjual tanahnya untuk pembangunan, serta tidak adanya perlindungan atau jaminan yang memadai bagi korban bencana alam atau bencana buatan manusia maka kemungkinan besar mereka akan menjadi miskin.

Ketiga, adanya hambatan dalam pengalokasian dana dan bantuan pemerintah yang dialokasikan untuk pengentasan kemiskinan tetapi pada kenyataannya banyak kasus penyelewengan dana, sehingga banyak dana yang tidak sampai pada rakyat, dan juga banyak pelayanan sosial seperti kesehatan dan pendidikan yang memadai tidak dapat diakses pada beberapa daerah pedalaman, sehingga hal ini tetap menempatkan kaum miskin berada pada garis kemiskinan.

Keempat, tidak diikutsertakannya keluarga miskin ke dalam proses sosial dan politik sehingga menjadikan orang miskin semakin termarjinalkan dan kurang pemberdayaan yang menyebabkan mereka sulit untuk membawa diri keluar dari kubangan kemiskinan.

Dalam Arsyad (2004), kemiskinan timbul karena ketidakmampuan masyarakat untuk ikut serta dalam proses perubahan, baik ketidakmampuan dalam kepemilika faktor produksi maupun kualitas faktor produksi yang memadai, sehingga tidak mendapatkan manfaat dari hasil proses pembangunan, artinya kemiskinan bisa disebabkan oleh hal yang alamiah (ketidakmampuan memanfaatkan faktor produksi serta hal yang tidak alamiah, artinya adanya kesalahan strategi pembangunan sehingga kebijakan yang dilakukan tidak dapat mengena kepada struktur sosial masyarakat yang ada, yang seharusnya pendapatan itu seharusnya bisa dinikmati.

Menurut Bradshaw (2005) menjelaskan ada lima penjelasan mengapa kemiskinan timbul, yaitu 1) Kelemahan-kelemahan individu (individual deficiencies) 2) Sistem budaya yang mendukung subkultur kemiskinan, 3) Distorsi-distorsi ekonomi-politik atau diskriminasi 
sosial-ekonomi, 4) Kesenjangan kewilayahan, dan 5) Asal-usul lingkungan yang bersifat kumulatif. Dibandingkan dengan Fitzpatrick (2001) bahwa sebab-sebab kemiskinan antara lain 1) miskin karena "gen kemiskinan", 2) miskin karena lingkungan karena lingkungan yang memiskinkan (cyrcle of deprivation), 3) miskin karena kegagalankegagalan kebijakan, 4) miskin karena adanya "rintangan-rintangan structural" (structural constraint), yaitu adanya kekuatan diluar dirinya yang menghalangi orang miskin untuk bergerak dan berubah menjadi tidak miskin, dan 5) miskin sebagai fungsi kapitalisme karena tenaga kerja cadangan diperlukan dalam kapitalisme. ${ }^{12}$

Dalam perspektif Islam, kemiskinan timbul karena berbagai sebab struktural. Pertama, kemiskinan timbul karena kejahatan manusia terhadap alam (QS 30:41) $)^{13}$ sehingga manusia itu sendiri yang kemudian merasakan dampak-nya (QS 42:30) ${ }^{14}$. Kedua, kemiskinan timbul karena ketidak pedulian dan kebakhilan kelompok kaya (QS 3: 180 ${ }^{15}$, QS 70:18 ${ }^{16}$ ) sehingga si miskin tidak mampu keluar dari lingkaran kemiskinan. Ketiga, kemiskinan timbul karena sebagian manusia bersikap dzalim, eksploitatif, dan menindas kepada sebagian manusia yang lain, seperti memakan harta orang lain dengan jalan yang batil

${ }^{12}$ Ibid., 14.

${ }^{13}$ Telah nampak kerusakan di darat dan di laut disebabkan karena perbuatan tangan manusia, supaya Allah merasakan kepada mereka sebahagian dari (akibat) perbuatan mereka, agar mereka kembali (ke jalan yang benar). al-Quran, 30:41.

${ }^{14}$ Dan apa saja musibah yang menimpa kamu Maka adalah disebabkan oleh perbuatan tanganmu sendiri, dan Allah memaafkan sebagian besar (dari kesalahankesalahanmu). Ibid.

${ }^{15}$ Sekali-kali janganlah orang-orang yang bakhil dengan harta yang Allah berikan kepada mereka dari karuniaNya menyangka, bahwa kebakhilan itu baik bagi mereka. sebenarnya kebakhilan itu adalah buruk bagi mereka. harta yang mereka bakhilkan itu akan dikalungkan kelak di lehernya di hari kiamat. dan kepunyaan Allah-lah segala warisan (yang ada) di langit dan di bumi. dan Allah mengetahui apa yang kamu kerjakan. Ibid.

${ }^{16}$ Serta mengumpulkan (harta benda) lalu menyimpannya (Maksudnya: orang yang menyimpan hartanya dan tidak mau mengeluarkan zakat dan tidak pula menafkahkannya ke jalan yang benar). Ibid. 
(QS 9:34 ${ }^{17}$ ), memakan harta anak yatim (QS 4: 2, 6, 10), dan memakan harta riba ${ }^{18}$ (QS 2:275 ${ }^{19}$ ). Keempat, kemiskinan timbul karena konsentrasi kekuatan politik, birokrasi, dan ekonomi di satu tangan. Hal ini tergambar dalam kisah Fir'aun, Haman, dan Qarun yang bersekutu dalam menindas rakyat Mesir di masa hidup Nabi Musa (QS 28:1-88). Kelima, kemiskinan timbul karena gejolak eksternal seperti bencana alam atau peperangan sehingga negeri yang semula kaya berubah menjadi miskin. Bencana alam yang memiskinkan ini seperti yang menimpa kaum Saba (QS 34: 14-15) atau peperangan yang menciptakan para pengungsi miskin yang terusir dari negeri-nya (QS 59:8-9).

\section{UKURAN KEMISKINAN}

Kemiskinan menurut ukurannya bisa dibedakan menjadi dua macam ukuran kemiskinan yang umum yaitu : 1) Kemiskinan Absolut, Konsep kemiskinan absolute ini menggunakan perkiraan tingkat pendapatan dan kebutuhan, perkiraan kebutuhan hanya dibatasi pada kebutuhan pokok atau kebutuhan dasar minimum yang memungkinkan seseorang untuk dapat hidup secara layak, bila pendapatan tidak dapat mencapai kebutuhan minimum, maka orang dapat dikatakan miskin..$^{20}$ Tetapi pendekatan ini memiliki kelemahan, yaitu kesulitan dalam menentukan kebutuhan minimum setiap negara

\footnotetext{
${ }^{17}$ Hai orang-orang yang beriman, Sesungguhnya sebahagian besar dari orangorang alim Yahudi dan rahib-rahib Nasrani benar-benar memakan harta orang dengan jalan batil dan mereka menghalang-halangi (manusia) dari jalan Allah. dan orang-orang yang menyimpan emas dan perak dan tidak menafkahkannya pada jalan Allah, Maka beritahukanlah kepada mereka, (bahwa mereka akan mendapat) siksa yang pedih, Ibid.

${ }^{18}$ Riba itu ada dua macam: nasiah dan fadhl. Riba nasiah ialah pembayaran lebih yang disyaratkan oleh orang yang meminjamkan. Riba fadhl ialah penukaran suatu barang dengan barang yang sejenis, tetapi lebih banyak jumlahnya karena orang yang menukarkan mensyaratkan demikian, seperti penukaran emas dengan emas, padi dengan padi, dan sebagainya. Riba yang dimaksud dalam ayat ini Riba nasiah yang berlipat ganda yang umum terjadi dalam masyarakat Arab zaman jahiliyah. (Ibid.).

${ }^{19}$ Orang-orang yang Makan (mengambil) riba, Ibid.

${ }^{20}$ Michael Todaro., "Economic Development in the Third World", Sixth Edition, Longman, 1997 dalam Lincoln Arsyad, Ekonomi Pembangunan Edisi 4, (Yogyakarta: Penerbit Sekolah Tinggi Ilmu Ekonomi YKPN, 2004), 238.
} 
yang memiliki adat dan budaya berbeda-beda, sehingga ukurannya pun tentu akan berbeda pula. 2) Kemiskinan Relatif, Pada konsep kemiskinan relatif ini berbeda dengan kemiskinan absolut, konsep ini menjelaskan bahwa orang yang memiliki tingkat pendapatan yang dapat memenuhi kebutuhan dasar minimum tetapi masih jauh lebih rendah dibandingkan dengan masyarakat sekitarnya, maka orang tersebut masih termasuk ke dalam golongan miskin ${ }^{21}$. Konsep ini merupakan perbaruan dari konsep kemiskinan absolut, yang mana garis kemiskinan akan mengalami perubahan bila tingkat hidup masyarakat berubah, sehingga dalam konsep kemiskinan relatif ini mengindikasikan bahwa kemiskinan akan selalu ada.

\section{INDIKATOR KEMISKINAN}

Kemiskinan merupakan hal yang komplek, ada beberapa indikator kemiskinan antara lain. Pertama, Tingkat Konsumsi Beras. Indikator ini menggunakan tingkat konsumsi beras per kapita sebagai indikator kemiskinan. Untuk daerah perdesaan, penduduk dengan tingkat konsumsi beras kurang dari $240 \mathrm{~kg}$ per kapita per tahun bisa digolongkan miskin. Sedangkan untuk daerah perkotaan adalah $360 \mathrm{~kg}$ per kapita per tahun..$^{22}$ Kedua, Tingkat Pendapatan. Terdapat batas pendapatan yang mengkategorikan garis batas kemiskinan . Ketiga, Kesejahteraan Rakyat. Pada publikasi UN (1961) yang berjudul International Definition and Measurement of Levels of Living: An Interim Guide disarankan 9 komponen kesejahteraan yaitu kesehatan, konsumsi makanan dan gizi, pendidikan, kesempatan kerja, perumahan, jaminan sosial, sandang, rekreasi, kebebasan. ${ }^{23}$

Dalam Jurnal Ekonomi Rakyat, indikator utama kemiskinan adalah; (1) terbatasnya kecukupan dan mutu pangan; (2) terbatasnya akses dan rendahnya mutu layanan kesehatan; (3) terbatasnya akses dan rendahnya mutu layanan pendidikan; (4) terbatasnya kesempatan

\footnotetext{
${ }^{21}$ Herman P Miller, “Rich Man, Poor Man” , dalam Ibid., 239.

${ }^{22}$ Sajogyo 1977 dalam Ibid, 240.

${ }^{23}$ Ibid.,242.
} 
kerja dan berusaha; (5) lemahnya perlindungan terhadap aset usaha, dan perbedaan upah; (6) terbatasnya akses layanan perumahan dan sanitasi; (7) terbatasnya akses terhadap air bersih; (8) lemahnya kepastian kepemilikan dan penguasaan tanah; (9) memburuknya kondisi lingkungan hidup dan sumberdaya alam, serta terbatasnya akses masyarakat terhadap sumber daya alam; (10) lemahnya jaminan rasa aman; (11) lemahnya partisipasi; (12) besarnya beban kependudukan yang disebabkan oleh besarnya tanggungan keluarga; (13) tata kelola pemerintahan yang buruk yang menyebabkan inefisiensi dan inefektivitas dalam pelayanan publik, meluasnya korupsi dan rendahnya jaminan sosial terhadap masyarakat

Ada juga kriteria miskin yang digunakan Badan Biro Statistik (BPS) di dalam menentukan kriteria keluarga miskin yang juga digunakan didalam pengalokasian Program BLT, seperti yang telah disosialisasikan oleh Departemen Komunikasi dan Informatika (2005), rumah tangga yang memiliki ciri rumah tangga miskin, yaitu: luas lantai bangunan tempat tinggal kurang dari $8 \mathrm{~m} 2$ per orang, jenis lantai bangunan tempat tinggal terbuat dari tanah/bambu/kayu murahan, jenis dinding tempat tinggal terbuat dari bambu/rumbia/kayu berkualitas rendah/tembok tanpa diplester, tidak memiliki fasilitas buang air besar/bersama-sama dengan rumah tangga lain, sumber penerangan rumah tangga tidak menggunakan listrik, sumber air minum berasal dari sumur/mata air tidak terlindung/sungai/air hujan, bahan bakar untuk memasak sehari-hari adalah kayu bakar/arang/minyak tanah, hanya mengkonsumsi daging/susu/ayam satu kali dalam seminggu, hanya membeli satu stel pakaian baru dalam setahun, hanya sanggup makan sebanyak satu/dua kali dalam sehari, tidak sanggup membayar biaya pengobatan di puskesmas/poliklinik, sumber penghasilan kepala rumah tangga adalah: petani dengan luas lahan 0, 5 ha. Buruh tani, nelayan, buruh bangunan, buruh perkebunan, atau pekerjaan lainnya dengan pendapatan di bawah Rp 600.000 per bulan, pendidikan tertinggi kepala kepala rumah tangga: tidak sekolah/tidak tamat $\mathrm{SD} /$ hanya SD, tidak memiliki tabungan/barang yang mudah dijual 
dengan nilai Rp 500.000, seperti: sepeda motor (kredit/non kredit), emas, ternak, kapal motor, atau barang modal lainnya.

\section{USAHA-USAHA PENGENTASAN KEMISKINAN}

Banyak usaha-usaha yang bisa dilakukan dalam pengentasan kemiskinan, tentunya terdapat banyak pendapat dari berbagai pihak dalam memandang metode apa yang paling tepat dalam pengentasan kemiskinan, pemerintah telah melakukan banyak program dan wacana dalam pengentasan kemiskinan, khususnya di negara Indonesia, juga telah didirikan lembaga-lembaga yang menangani masalah kemiskinan ini, namun juga banyak usaha-usaha tersebut yang tidak mengena sasaran, bahkan banyak yang diselewengkn oleh pihak yang kurang bertanggung jawab. Namun, dalam hal ini penulis akan mencoba memaparkan tentang beberapa usaha pengentasan kemikinan, antara lain Lincoln Arsyad menjabarkan beberapa penyebab kemiskinan antara lain:

Pembangunan pertanian. Pembangunan suatu Negara terletak pada kuatnya sektor basis, sektor pertanian merupakan sektor yang berperan penting dalam pengentasan kemiskinan terutama di wilayah pedesaan, dengan adanya diversifikasi pertanian, misalnya pengadaan bibit unggul, peningkatan tekhnologi, serta penyuluhan kepada para petani, serta peran pemerintah dalam penningkatan suber daya petani, sehingga akan meningkatkan output dan menghasilkan profitabilitas yang lebih, terbukti revolusi teknologi padi, termasuk pembangunan irigasi pada tahun 1969 dan 1987, ketika varietas unggul menggantikan varietas tradisional, pendapatan petani meningkat dua kali lipat. ${ }^{24}$

Pembangunan sumber daya manusia. Perbaikan akses pelayanan sosial bagi rakyat miskin, baik dari segi pendidikan, kesehatan dan gizi. Jika orang miskin mendapatkan pendidikan yang layak, maka hal ini akan sangat membantu dalam pengentasan kemiskinan dalam jangka panjang, mendidik generasi untuk menjadi insan yang berilmu dan memiliki ketrampilan, sehingga akan mengerti untuk

\section{${ }^{24}$ Ibid.}


memperjuangkan hidup, dan mengerti akan pentingnya berusaha meningkatkan taraf hidup, sehingga dalam jangka panjang investasi ini akan dapat mengurangi angka kemiskinan pada waktu jangka panjang, selain itu kesehatan, jika rakyat miskin terjamin dalam mendapatkan pelayanan kesehatan, gizi serta papan yang bersih dan terjamin, kesehatan yang baik akan meningkatkan produktifitas golongan miskin yaitu meningkatkan daya kerja, mengurangi hari tidak bekerja sehingga output yang dihasilkan pun akan meningkat, demikian juga jika didukung dengan rasa aman karena terpenuhinya keamanan, tempat tinggal yang nyaman serta gizi yang tercukupi. Jika semua itu dapat terpenuhi dengan baik, akan sangat besar angka kemiskinan sedikit demi sedikit akan berkurang.

Peranan Lembaga Swadaya Masyarakat. Lembaga-lembaga Swadaya masyarakat lebih berperan penting dalam pengentasan kemiskinan, karena bisa secara langsung menyetuh pada masyarakat binaan terutama masyarakat miskin, apalagi jika lembaga tersebut ikut berperan dalam program pemerintah penanggulangan kemiskinan.

Kita mengetahui bahwasannya agama Islam adalah Negara yang sangat menjunjung nilai sosial, serta mencitakan kehidupan yang adil, makmur, sejahtera, tenteram dan harmonis, demi mewujudakan hal tersebut maka perlu meminimalisir kesenjangan strata sosial dan realitas kemiskinan di tengah-tengah umat. Fakta sosial menunjukkan kurang termanfaatkannya serte terkelolanya potensi ekonomi umat. Kemiskinan sendiri memiliki sejarah yang cukup panjang sejak zaman jahiliyyah yang tercermin dengan adanya kerusakan moral, budaya dan tatanan masyarakat. ${ }^{25}$ Secara genuine Islam memusuhi kemiskinan, hal tersebut terbukti dengan banyaknya pernyataan-pernyataan di dalam al-Qur'an maupun hadits yang menganjurkan kepada umat Islam untuk memberantas kemiskinan, dikatakan di dalam al-Qur'an QS. Al-Ma'un 1-3:26

${ }^{25}$ Subki Risya, Zakat Untuk Pengentasan Kemiskinan, (Jakarta: PP.LAZIS NU, 2009), 13.

${ }^{26}$ Al-Qur'an, 1-3:107. Yang artinya tahukah kamu (orang) yang mendustakan agama? Itulah orang yang menghardik anak yatim dan tidak menganjurkan memberi Makan orang miskin 
Rasulullah SAW juga pernah memberi ultimatum seraya bersabda bahwa tidak beriman seseorang, dimana ia tidur dengan kekenyangan, tetapi tetangganya merasakan kelaparan, hal ini semakin menegaskan bahwa Islam sebagai pembawa rahmat bagi seluruh alam, salah satunya dengan memerangi kemiskinan. Di lain pihak imam Ali juga memperingatkan bahwa kemiskinan merupakan instrumen yang dapat menjerumuskan manusia ke dalam kekufuran. ${ }^{27}$ Yūsuf al-Qard\{awi mengemukakan, bahwa kemiskinan ini bisa terentaskan kalau setiap individu mencapai taraf hidup yang layak didalam masyarakat. Dan untuk mencapai taraf hidup yang diidealkan itu Islam memberikan kontribusi berbagai cara dengan jalan sebagai berikut. ${ }^{28}$

Bekerja, Setiap orang yang hidup dalam masyarakat Islam, diharuskan untuk bekerja dan berusaha mencari nafkah di bumi ini dengan sungguh-sungguh dalam hal ini adalah memiliki etos kerja yang tinggi, serta diperintahkan makan dari rizki Allah SWT sebagaimana disebutkan dalam QS. Al-Mulk 15 :

"Dialah yang manjadikan bumi itu rumah bagimu, maka berjalanlan di segala penjurunya dan makanlah sebagian rizki-Nya"

Bekerja merupakan suatu yang utama untuk memerangi kemiskinan, modal pokok untuk mencapai kekayaan, dan faktor dominan dalam menciptakan kemakmuran dunia. Dalam tugas ini, Allah telah memilih manusia sebagai khalifah untuk mengelola bumi, sebagaimana yang telah dinyatakan oleh Allah, bahwa hal itu pernah diajarkan oleh Nabi Saleh a.s kepada kaumnya, sebagimana disebutkan dalam QS.Hud 61:

“Wahai kaumku, sembahlah Allah, sekali-kali tidak ada bagimu tuhan melainkan Dia, Dia telah menciptakan kamu dari tanah (liat) dan menjadikan kamu sebagai pemakmurmu".

Membantu Keluarga yang Lemah, Untuk memerangi kemiskinan, di dalam syari'at Islam sudah menjadi dasar pokok bahwa sen-

\footnotetext{
${ }^{27}$ Ibid.

${ }^{28}$ Ibid., 20.
} 
jata yang harus digunakan adalah bekerja dan berusaha. Islam tidak menutup mata dengan, dengan mengentaskan mereka dari lembah kemiskinan dan kemelaratan, serta menghindarkan mereka dari perbuatan rendah dan hina, seperti mengemis dan meminta-minta. Sebagaimana Rosulullah SAW bersabda :

"Seseorang diantara kalian yang membawa tali, kemudian ia datang dengan seikat kayu bakar di atas punggungnya, lalu ia jual kayu bakar itu sehingga ia dapat menjaga mukanya (kehormatannya) lebih baik daripada meminta-minta kepada orang lain (yang nantinya) akan diberi atau tidak" (HR. Al-Bukhari)

Konsep yang dikemukakan oleh Islam dalam menanggulangi hal tersebut adalah adanya jaminan antara anggota keluarga dalam suatu rumpun keluarga, Islam telah menjadikan antara anggota keluarga saling menjamin dan mencukupi. Sebagian meringankan penderitaan anggota yang lain. Faktor kasih sayang, cinta mencintai, dan saling membantu adalah ikatan serumpun kerabat. Demikinlah sebenarnya hakekat hubungan alami. Hal ini telah didukung oleh kebenaran syari'at Islam, sebagaimana yang disebutkan dalm QS. Al- Anfal 75 :

“Dan anggota keluarga, sebagiannya lebih berhak terhadap anggota keluarga yang lain, menurut kitab Allah"

Pengentasan Kemiskinan dengan Zakat, Islam mewajibkan setiap orang sehat dan kuat, untuk bekerja dan berusaha mencapai rizki Allah SWT guna mencukupi dirinya dan keluarganya, sehingga sanggup mendermakan hartanya di jalan Allah. Sebagaimana kewajiban mengeluarkan zakat, tertera dalam QS. An-Nur 56

"Katakanlah: "Taat kepada Allah dan taatlah kepada rasul; dan jika kamu berpaling Maka Sesungguhnya kewajiban Rasul itu adalah apa yang dibebankan kepadanya, dan kewajiban kamu sekalian adalah semata-mata apa yang dibebankan kepadamu. dan jika kamu taat kepadanya, niscaya kamu mendapat petunjuk. dan tidak lain kewajiban Rasul itu melainkan menyampaikan (amanat Allah) dengan terang". 
Zakat dikeluarkan bagi orang-orang yang tidak mampu berusaha dan tidak mampu bekerja, serta tidak mempunyai harta warisan atau simpanan guna mencukupi kebutuhan hidupnya, ia berhak mendapatkan jaminan dari keluarganya yang mampu dengan memberikan bantuan serta bertanggung jawab terhadap nasib keluarga yang miskin. Akan tetapi tidak semua fakir miskin memiliki keluarga yang mampu dan sanggup memberikan bantuan, oleh karena itu Islam tidak akan membiarkan begitu saja nasib fakir miskin yang terlantar. Sesungguhnya allah SWT telah menetapkan bagi mereka suatu hak tertentu di dalam harta orang-orang kaya, dan suatu bagian yang tetap dan pasti, yaitu melalui zakat. Dalam Hadits disebutkan:

“Dari Ibnu 'Abbas r.a: Bahwasannya Nabi SAW mengutus mu'adz ke Yaman, dan Ibnu 'Abbas menyebutkan hadits itu, dan dalam hadits itu tersebut sabda Nabi SAW: "Sesungguhnya Allah telah mewajibkan zakat atas mereka dari harta-hartanya, diambil dari orang-orang kayanya dan diserahkan kepada fakir-fakirnya". (Muttafaq 'alaih ${ }^{29}$

Pada masa kejayaan Islam, banyak fakta sejarah yang menyebutkan bahwa zakat bisa mengurangi angka kemiskinan, Umar bin Khattab misalnya yang menjadikan Yaman sebagai satu propinsi yang mampu mengentaskan kemiskinan, hal ini dibuktikan bahwa gubernur Yaman waktu itu, Mu'adz bin Jabal, mengirim sepertiga daro total hasil zakat dari propinsi tersebut ke Madinah, separuh di tahun berikutnya, dan semua hasil di tahun ketiga, pengentasan kemiskinan juga ditemui di masa kepemimnpinan Umar bin Abdul Azis, dimana pada waktu itu sudah tidak diketemukan lagi orang miskin di Negara itu (Monzer Kahf, 1999). ${ }^{30}$ Zakat ini dibayarkan bagi yang telah mencapai batas kepemilikan harta tertentu (nisab). Zakat yang dibayarkan oleh orang-orang kaya kepada orang yang membutuhkan, tidak hanya menimbulkan kebaikan dan manfaat bagi orang yang menerima. Lebih dari itu, zakat juga mendatangkan kebaikan bagi 213.

${ }^{29}$ Muh. Sjarief Sukandy, Tarjamah Bulughul Maram (Bandung: Al-Ma'arif, 1984),

${ }^{30}$ Risya, Zakat,15. 
yang menunaikannya terkait dengan fungsi zakat yang menyucikan harta, dan berpotensi untuk mendapatkan pahala yang berlipat.

Zakat membentuk perilaku moralitas bagi pemeluknya, dalam prosesnya yang dientaskan dulu adalah golongan orang-orang kaya (Muzakki). Sebab, dengan zakat yang mereka salurkan, mereka mengentaskan kemiskinan yang terdapat di dalam diri mereka sendiri, sperti sifat tamak, serakah, kikir, takabur dan lain-lain, jadi, zakat ini memliki dua dimensi yang mana pengentasan terjadi dari segi ruhaniyah (habl min Allah SWT) bagi muzakki, baru dampaknya menyebar kepada aspek zakatnya (mustahiq) (habl min al-nas). ${ }^{31} 1$ ) Adanya hak-hak material lain. Hak ini wajib dipenuhi oleh orang muslim terkait dengan tanggung jawab yang dikenakan terhadapnya. Hakhak tersebut merupakan sumber dana bantuan bagi orang-orang fakir dan miskin yang dapt membantu pengentasan kemiskinan, hak-hak tersebut diantaranya: a) Hak bertetangga, b) Korban hari raya haji (Idul Adha), c) Melanggar sumpah, d) Kafarah, e) Fidyah bagi orang lanjut usia, f) al-Hadyu (pelanggaran dalam ibadah haji), g) Hak tanaman pada saat mengetan, h) Hak mencukupi fakir miskin. 2) al-Khizanah al-Islämiyah (sumber material dalam Islam atau Baitul Mal), Sumbersumber material dalam Islam disini meliputi hak milik negara dan kekayaan-kekayaan umum, yang dikelola dan diurus oleh pemerintah, baik yang digarap langsung maupun yang dikerjakan bersama, seperti harta wakaf, sumber kekayaan alam, dan barang tambang yang ditetapkan dalam Islam yang diambil apabila dalam distribusi kekeyaan yang diambil dari zakat untuk para fakir miskin tidak mencukupi. 3) Sedekah, Islam juga berusaha membentuk pribadi yang luhur, dermawan, dan murah hati. Pribadi yang luhur adalah insan yang suka memberikan lebih dari apa yang diminta, suka mendermakan lebih dari apa yang diwajibkan. Ia suka memberikan sesuatu, kendati tidak diminta dan tidak dituntut terlebih dahulu. Ia suka berderma (memberi infaq) dikala siang maupun malam. Sebagaimana Allah SWT telah berfirman dalam QS. Al-Baqarah 245:

${ }^{31} \mathrm{Ibid}, 124-125$. 
"Siapakah yang mau memberi pinjaman kepada Allah, pinjaman yang baik (menafkahkan hartanya di jalan Allah), Maka Allah akan meperlipat gandakan pembayaran kepadanya dengan lipat ganda yang banyak. dan Allah menyempitkan dan melapangkan (rizki) dan kepadaNya-lah kamu dikembalikan"

al-Maududi juga menambahkan bahwa salah satu cara pengentasan kemiskinan adalah dengan cara hemat, Islam memperhatikan dan mengawasi perputaran kekayaan pada seluruh masyarakat, danditentukannya satu bagian dari harta orang kaya untuk diberikan kepada fakir miskinpada satu sisi, dan pada sisi lain diperintahkanya kepada tiap-tiap individu dalam mengeluarkan hartanya (pembelanjaan), hingga keseimbangan dalam pembagian kekayaan tidak terganggu karena sikap berlebihan individu tersebut dalam menggunakan harta kekayaannya. ${ }^{32}$ Dalam QS. Al-Furqan 67:

"Dan orang-orang yang apabila membelanjakan (harta), mereka tidak berlebihan, dan tidak (pula) kikir, dan adalah (pembelanjaan itu) di tengah-tengah antara yang demikian"

Dalam hal ini Islam menganjurkan kepada umatnya untuk membelanjakan harta tidak diluar batas kemampuan ekonominya, hingga pengeluaran lebih besar daripada pendapatan yang pada akhirnya menjerumuskan dirinya sendiri kedalam hutang, mengemis, merampas bahkan hingga sampai menjual apa-apa yang dimilikinya sehingga menjerumuskan diri masuk kedalam kemiskinan. Oleh karena itu tidak dianjurkan bagi umat Islam untuk bersikap boros, lebih baik memberikan harta yang lebih tersebut untuk saudara-saudara yang membutuhkan daripada menggunakan untuk berfoya-foya dan bersenang-senang.

\section{PENUTUP}

Kemiskinan sendiri adalah keadaan dimana seseorang tidak dapat memenuhi kebutuhan dasarnya, dalam hal ini kebutuhan tersebut

${ }^{32}$ Abu A'la al-Maududi, Dasar dasar ekonomi dalam Islamdan Berbagai Sistem Masa Kini, (Bandung: Al-Ma,arif, 1980). 
adalah hal dalam ruang lingkup multidimensi, orang miskin tidak hanya tidak dapat makan, berpakaian dan tidak memiliki rumah saja, orang miskin juga karena tidak terpenuhinya rasa aman, ketidak mampuan dalam mengakses pelayanan sosial dan kebijakan pemerintah. Islam sendiri memandang kemiskinan

Kemiskinan disebabkan sedikitnya kesempatan kerja yang memungkinkan terjadinya pengangguran, hilangnya habitat serta adanya kerusakan lingkungan, tidak mengenanya kebijakan pemerintah dan ketertinggalan orang miskin dalam sistem sosial, adanya "gen miskin" yang berlanjut terus menerus, adanya kekuatan luar yang menjadikan orang miskin tetap berada pada kubangan kemiskinan, sikap yang tidak hemat, adanya cyrcle of deprivation, ketidakmampuan seseorang dalam memanfaatkan faktor produksi yang ada, ketidakmampuan dalam mengekses pelayanan sosial yang ada.

Ukuran kemiskinan terdapat kemiskinan absolut yaitu kemiskinan yang timbul karena ketidakmampuan pendapatan masyarakat di dalam memenuhi kebutuhan dasar. Sedangkan kemiskinan relative diukur dengan membandingkan dengan lingkungan di sekitar, kemiskinan relative ini timbul karena kondisi ekonomi seseorang berada pada tingkat yang lebih rendah dibandingkan dengan lingkungan sekitar.

Indikator kemiskinan dapat diukur dengan tingkat konsumsi beras, tingkat pendapatan serta kesejahteraan rakyat. Indikator kemiskinan juga dapat ditandai dengan keterbatasan masyarakat di dalam memanfaatkan faktor produksi baik itu secara alamiah dari diri mereka sendiri, maupun ketidakmampuan yang disebabkan oleh faktor luar.

Usaha-usaha seperti pembangunan pertanian, pembangunan sumberdaya manusia, dan pemanfaatan lembaga-lembaga kemasyarakatan untuk membuat kebijakan pemerintah lebih efektif, kemudian Islam memiliki cara sendiri untuk pengentasan kemiskinan. Dalam mengatasi kemiskinan, maka seseorang harus rajin bekerja, peduli dengan sesama, kepedulian pemerintah terhadap kaum miskin, bagi yang mampu hendaknya memenuhi kewajiban-kewajiban seperti 
membayar zakat dan pemenuhan hak-hak dan tanggung jawab yang harus dipenuhinya, serta bergaya hidup hemat. Tentunya di dalam pelaksanaannya diharapkan semua pihak dianjurkan untuk meningkatkan kesadarannya, sebagai khalifah yang diberikan tanggung jawab. Sehingga akan terwujud kesinkronan dalam tatanan kehidupan bermasyarakat, serta untuk mencapai keberhasilan pembangunan Negara yang akhirnya akan tercipta ketenangan hidup.

\section{DAFTAR RUJUKAN}

Abu A'la al-Maududi, 1980. Dasar dasar ekonomi dalam Islam dan Berbagai Sistem masa Kini. Bandung: Al-Ma,arif.

Arsyad, Lincoln., 2004. Ekonomi Pembangunan, Edisi 4, Penerbit Sekolah Tinggi Ilmu Ekonomi YKPN. Yogyakarta.

Berita Resmi Statistik. No 45/07/Th. XIV Tanggal 1 Juli 2011. http:// www.bps.go.id/ (Diakses Tanggal 15 November 2011).

Hardojo, Antonio Pradjasto, dkk. 2008. Dahulukan Si Miskin. PT. LKiS Pelangi Aksara. Yogyakarta.

an-Nabhani, Taqiyuddin, Nidzamul Iqtishadi fil Islam, (Beirut: Darul Ummah,1990)

al-Qur'an dan Terjemah Bahasa Indonesia. Penerbit Menara Kudus. Kudus.

Risya, Subki. 2009. Zakat Untuk Pengentasan Kemiskinan. PP.LAZIS NU. Jakarta.

Sahdan, Gregorius. 2005. Menaggulangi Kemiskinan. Dalam Jurnal Ekonomi Rakyat. Edisi Maret 2005.

Sukandy, Muh.Sjarief. 1984. Tarjamah Bulughul Maram . Penerbit AlMa'arif. Bandung.

Tim Penulis, 2010. Masalah Kemiskinan Dalam Islam. Http://kanal3. wordpress.com/ (Diakses tanggal 15 November 2011).

www.kompas.com. 